\title{
Standardizing the determination of the molecular backscatter coefficient profiles for LALINET lidar stations using ERA-Interim Reanalysis.
}

\section{Estandarización en la determinación de los perfiles del coeficiente de retrodispersión molecular para las estaciones lidar elásticas de LALINET utilizando el reanálisis ERA- Interim.}

\author{
Albert Rodríguez Vega* and Juan Carlos Antuña Marrero \\ Atmospheric Optics Group of Camaguey. Meteorological Institute of Cuba
}

(”) E-mail albertrodriguezvega@gmail.com

Received: 06/10/2016 Accepted: 13/02/2017

DOI: 10.7149/OPA.50.1.49013

\begin{abstract}
:
The molecular backscatter signal is necessary in aerosol lidars to determine the aerosol backscatter and extinction. It is derived using atmospheric temperature and pressure profiles from simultaneous soundings or climatological values from radiosonde measurements. In cases when no radiosonde measurements are available at or near the lidar stations the U.S. Standard Atmosphere is commonly used. Although the atmospheric reanalysis can also be used to obtain the atmospheric temperature and pressure profiles at any station, we found no reports of its use for this purpose. Therefore, the goal of this research is to compare molecular backscatter coefficients derived from radiosonde measurements with ones derived using the ERA-Interim reanalysis and the U.S. Standard Atmosphere 1976 (USSA-1976), for the locations of the lidar stations from the Latin America Lidar Network (LALINET). The differences between radiosonde measurements and ERA-Interim temperature profiles are smaller than the differences between radiosonde measurements and the USSA-1976 temperature profiles. In many stations, the differences between the temperature in radiosonde measurements and ERA-Interim are smaller than $2 \mathrm{~K}$ and the greatest differences are about $4 \mathrm{~K}$. However, the differences between temperature in radiosonde measurements and in the USSA-1976 are smaller than $10 \mathrm{~K}$ only in three stations, and the greatest differences are about $20 \mathrm{~K}$. The profiles of relative differences of the molecular backscatter coefficients between radiosonde measurements and ERA-Interim show negative values at most of the pressure levels. Positive values greater than 0.5 $\%$ are only observed above $8 \mathrm{~km}$. However, the profiles of relative differences of the molecular backscatter coefficients between radiosonde measurements and the USSA-1976 shows positive values from surface to $12 \mathrm{~km}$ in all stations. Only in four stations are observed negative differences above 14 $\mathrm{km}$ with values smaller than $-5 \%$. Comodoro Rivadavia presents the best behavior because is located near to 45 degree of latitude, but even in this station the differences between radiosonde measurements and the USSA-1976 are bigger than those observed between radiosonde measurements and ERA-Interim.
\end{abstract}

Key words: Molecular backscatter coefficient; Radiosonde measurements; ERA-Interim reanalysis; LALINET; U.S. Standard Atmosphere 1976

RESUMEN: La señal lidar retrodispersada por moléculas es necesaria en los lidares para determinar la retrodispersión y la extinción por aerosoles. Esta se determina utilizando perfiles de temperatura y presión atmosférica, a partir de valores simultáneos o climatológicos de las mediciones de radiosondas. En los casos cuando no existen mediciones de radiosondas en las estaciones de lidar o cercanos a ellas, se emplea comúnmente la atmósfera estándar (Atmósfera Estándar de Estados Unidos). Aunque los reanálisis atmosféricos también se pueden utilizar para obtener los perfiles de temperatura y de presión atmosférica en cualquier estación, no se ha encontrado ningún informe o reporte de su uso para este propósito. Por lo tanto, el objetivo de esta investigación es comparar los coeficientes de retrodispersión moleculares derivadas de las mediciones de radiosondas con las obtenidas utilizando el reanálisis ERA-Interim y la atmósfera estándar de Estados Unidos 1976 (USSA- 
1976), para la ubicación de las estaciones lidar de la Red Latinoamericana de Lidares (LALINET). Las diferencias entre las mediciones de radiosonda y los perfiles de temperatura de ERA-Interim son más pequeñas que las diferencias entre las mediciones de radiosonda y los perfiles de temperatura USSA1976. En muchas estaciones, las diferencias entre la temperatura en las mediciones de radiosonda y ERA-Interim tienen valores menores de $2 \mathrm{~K}$ y las mayores diferencias son alrededor de $4 \mathrm{~K}$. Sin embargo, las diferencias entre la temperatura en las mediciones de radiosonda y en el USSA-1976 son más pequeñas que $10 \mathrm{~K}$ sólo en tres estaciones, y las mayores diferencias son alrededor de $20 \mathrm{~K}$. Los perfiles de las diferencias relativas de los coeficientes de retrodispersión moleculares entre las mediciones de radiosonda y el ERA-Interim muestran valores negativos en la mayoría de los niveles de presión. Los valores positivos superiores a $0.5 \%$ sólo se observan por encima de $8 \mathrm{~km}$. Sin embargo, los perfiles de las diferencias relativas de los coeficientes de retrodispersión molecular entre las mediciones de radiosonda y la USSA-1976 muestran valores positivos desde la superficie hasta $12 \mathrm{~km}$ en todas las estaciones. Sólo en cuatro estaciones se observan diferencias negativas por encima de 14 $\mathrm{km}$, con valores inferiores a $-5 \%$. Comodoro Rivadavia presenta el mejor comportamiento pues se encuentran ubicada cerca de 45 grados de latitud, pero incluso en esta estación las diferencias entre las mediciones de radiosonda y la USSA-1976 son mayores que los observados entre las mediciones de radiosonda y ERA-Interim.

Palabras clave: Coeficiente de retrodispersión molecular; mediciones de radiosondeos; reanálisis ERA-Interim; LALINET; Atmósfera Estándar de Estados Unidos de 1976

\section{REFERENCES AND LINKS / REFERENCIAS Y ENLACES}

[1]. Povey, A. C.; Grainger, R. G.; Peters, D. M. and Agnew, J. L., "Retrieval of aerosol backscatter, extinction, and lidar ratio from Raman lidar with optimal estimation." Atmos. Meas. Tech., 7, 757-776 (2014) https://doi.org/10.5194/amt-7-757-2014

[2]. Fugii T, Fukuchi T.2005. "Laser Remote Sensing." Taylor and Francis, Boca Raton, FL, 2005.

[3]. Matthias M., Böckmann C., Freudenthaler V., Pappalardo G., Bösenberg J., Amiridis V., Amodeo A., Ansmann A., Balis D., Boselli A., Chaykovski A., Chourdakis G., Comeron A., Delaval A., De Tomasi F., Eixmann R., Frioud M., Hågård A., Iarlori M., Komguem L., Kreipl S., Larchevêque G., Linné H., Matthey R., Mattis I., Papayannis A., Pelon J., Perrone R. M., Persson R., Resendes D. P., Rizi V., Rocadenbosch F., Rodriguez J. A., Sauvage L., Schneider J., Schumacher R., Shcherbakov V., Simeonov V., Wandinger U., Wang X., Wiegner M. Zerefos C, 2002. "Lidar intercomparisons on algorithm and system level in the frame of EARLINET." Rep. 337. (Max-Planck-Institut für Meteorologie, Hamburg, Germany, 2002).

[4]. Böckmann, C., U. Wandinger, A. Ansmann, J. Bösenberg, V. Amiridis, A. Boselli, A. Delaval, F. De Tomasi, M.Frioud, I. Videnov Grigorov, A. Hågård, M. Horvat, M. Iarlori, L. Komguem, S. Kreipl, G. Larchevêque, V. Matthias, A. Papayannis, G. Pappalardo, F. Rocadenbosch, J. A. Rodrigues, J. Schneider, V. Shcherbakov, and M. Wiegner. "Aerosol lidar intercomparison in the framework of the EARLINET project. 2. Aerosol backscatter algorithms." Appl. Opt. 43, 977-983, (2004). https://doi.org/10.1364/A0.43.000977

[5]. Reddy, B.S., Kumar, Y.B. 2013. "Micro Pulse Lidar as a Tool for Active Remote Sensing of Atmospheric Particulate", Inter. J. Eng. Technol. 5 (4): 3394-3403.

[6]. Bucholtz, A. "Rayleigh-scattering calculations for the terrestrial atmosphere," Appl. Optics, 34, 27652773 (1995).

https://doi.org/10.1364/A0.34.002765

[7]. Weitkamp, C. "Lidar. Range-resolved optical remote sensing of the Atmosphere," Springer, NY. (2005)

[8]. Ansmann, A., Wandinger, U., Riebesell, M., Weitkamp, C., Michaelis, W. "Independent measurement of extinction and backscatter profiles in cirrus clouds by using a combined Raman elastic-backscatter lidar. Appl. Opt., 31, 7113-7131 (1992).

https://doi.org/10.1364/A0.31.007113

[9]. Antuña-Marrero, J.C., Landulfo, E., Estevan, R., Barja, B., Robock, A., Wolfram, E., Ristori, P., Clemesha, B., Zaratti, F., Forno, R., Armandillo, E., Bastidas, A.E., de Frutos, A.M., Whiteman, D.N., Quel, E., Barbosa, H.M.J., Lopes, F., Montilla-Rosero, E., Guerrero-Rascado, J.L. "LALINET: The first Latin American-born regional atmospheric observational network." Bull. Amer. Meteor. Soc. (in press) https://doi.org/10.1175/BAMS-D-15-00228.1 
[10]. Guerrero-Rascado J.L., Landulfo, E., Antuña, J.C., Barbosa, H.M.J., Barja, B., Bastidas, A.E., Bedoya, A.E., da Costa, R., Estevan, R. Forno, R.N., Gouveia, D.A. Jimenez, C., Larroza, E.G., Lopes, F.J.S., MontillaRosero, E., Moreira, G.A., Nakaema, W.M., Nisperuza, D., Alegria, D., Manera, M., Otero, L., Papandrea, S., Pallota, J.V., Pawelko, E., Quel, E.J., Ristori, P., Rodrigues, P.F., Salvador, J., Sanchez, M., Silva, A. "Latin American Lidar Network (LALINET): diagnosis on network instrumentation," J. Atmos. and Sol-Terr Phy. 138-139, 112-120 (2016). https://doi.org/10.1016/i.jastp.2016.01.001

[11]. Barbosa, H.M.J., Lopes, F.J.S., Silva, A., Nisperuza, D., Barja, B., Ristori, P., Gouveia, D.A., Jimenez, C., Montilla, E., Mariano, G.L., Landulfo, E., Bastidas, A., Quel, E.J. 2014. "The first ALINE measurements and intercomparison exercise on lidar inversion algorithms," Opt. Pura Apl., 47 99-108, (2014) https://doi.org/10.7149/0PA.47.2.109

[12]. Bösenberg, J., Hoff, R., Ansmann, A., Müller, D., Antuña, J., Whiteman, D., Sugimoto, N., Apituley, A., Hardesty, M., Welton, J., Eloranta, E., Arshinov, Y., Kinne, S., Freudenthaler, V. "Plan for the Implementation of the GAW Aerosol Lidar Observation Network (GALION)," WMO/TD, 178, (2007).

[13]. Durre I., Russell S.V. and Wuertz D.B., “Overview of the Integrated Global Radiosonde," Archive. J. Climate, 19, 53-68 (2006). https://doi.org/10.1175/JCLI3594.1

[14]. Durre I, Russell SV, Wuertz BA. "Robust Automated Quality Assurance of Radiosonde Temperatures." J. Appl. Meteor. Climatol., 47, 2081-2095 (2008) https://doi.org/10.1175/2008JAMC1809.1

[15]. Dee, D. P., and Coauthors, "The ERA-Interim reanalysis: Configuration and performance of the data assimilation system.” Quart. J. Roy. Meteor. Soc., 137, 553-597,(2011). https://doi.org/10.1002/qi.828

[16].Zappa, G., L. Shaffrey and K. Hodges, "Can Polar Lows be Objectively Identified and Tracked in the ECMWF Operational Analysis and the ERA-Interim Reanalysis?," Mon. Wea. Rev., 142, 2596-2608., (2014). https://doi.org/10.1175/MWR-D-14-00064.1

[17]. Berrisford, P., Dee, D., Fielding, K., Fuentes, M., Kållberg, P., Kobayashi, Sh., Uppala, S. “The ERA-Interim archive. Version 1.0." ERA Report Series. European Centre for Medium Range Weather Forecasts. (2009)

[18]. Lewis H. “Geodesy calculations in ROPP.” GRAS SAF Report 02. Met Office, UK (2007).

[19]. U.S. Standard Atmosphere, 1962, U.S. Government Printing Office, Washington, D.C., (1962).

[20]. NOAA (National Oceanic and Atmospheric Administration): U.S. Standard Atmosphere, Tech. Rep. NOAA Doc. S/T 76-1562, U.S. Government Printing Office, Washington, D.C., (1976).

[21]. Russell PB, Swissler TJ, McCormick MP. 1979. "Methodology for error analysis and simulation of lidar aerosol measurements.” Appl. Opt., 18 (1979).

https://doi.org/10.1364/A0.18.003783

\section{Introduction}

Lidar (LIght Detection And Ranging) is an active remote sensing technique used to obtain information both for the spatial and temporal distribution of atmospheric components [1]. This technique is similar to radar because both techniques use the time of flight of an electromagnetic signal from a pulsed source to determine the distance to the scatterer volume [2]. The difference consists in the fact that the radar uses radio waves while the lidar uses laser radiation in different regions of the spectrum. The analysis of the lidar measured returning signal is performed with the lidar equation, which describes this signal as a function of atmospheric and system parameters $[3,4]$ :

$$
P(\lambda, z)=P_{0}(\lambda) \cdot C \cdot \frac{o(z)}{z^{2}} \cdot \beta\left(\lambda_{L}, z\right) \cdot \exp \left(-2 \int_{0}^{z} \alpha\left(\lambda_{L}, \zeta\right) d \zeta\right)
$$

where $P(\lambda, z)$ is the backscattered laser power at wavelength $\lambda$ from range $z$ and $P_{0}(\lambda)$ is the emitted laser power at wavelength $\lambda$. $C$ is the range independent system constant and $O(z)$ is the overlap function. $\beta\left(\lambda_{L}, z\right)$ stands for the atmospheric backscatter coefficient and $\alpha\left(\lambda_{\mathrm{L}}, \zeta\right)$ is the atmospheric extinction coefficient. $\mathrm{C}=$ $\eta A c \tau_{L} / 2$ depends on efficiency $\eta$ of the detector system, receiving telescope area $A$, and pulse width of the laser $\tau_{\mathrm{L}}$. The speed of light is $\mathrm{c}$. 
In the case of elastic lidars the problem consists in determining two unknowns, the molecular and aerosols backscatter coefficients with only one equation. The solution is to determine the molecular backscatter using an additional equation [5]:

$$
\text { CORRIGENDUM } \quad \beta_{\text {mol }}(R, \lambda ; p, T)=\frac{8 \pi^{3}\left(m_{\text {air }}{ }^{2}-1\right)^{2}}{3 \lambda^{4} N_{S}{ }^{2}} \cdot \frac{6+3 \gamma}{6-7 \gamma} \cdot N_{S} \cdot \frac{T_{0}}{p_{0}} \cdot \frac{p(z)}{T(z)} \quad \text { (2) (Wrong) }
$$

where $m_{\text {air }}$ is the refractive index of the air, $\gamma$ is the depolarization factor $(\gamma$ is $0.0301,0.02$, and 0.0273 for 355,532 , and $1064 \mathrm{~nm}$, respectively) [6], $N_{S}$ is the molecular number density $\left(N_{S}=2.547 \cdot 10^{19} \mathrm{~cm}^{-3}\right)$ for standard atmospheric conditions at ground level $\left(p_{0}=1013.25 \mathrm{hPa}, \mathrm{T}_{0}=15^{\circ} \mathrm{C}\right.$ and $\left.0.03 \% \mathrm{CO}_{2}\right)$. Profiles of temperature $\mathrm{T}(\mathrm{z})$ and pressure $\mathrm{p}(\mathrm{z})$ are obtained from radiosonde measurements. In absence of radiosonde measurements $\mathrm{T}(\mathrm{z})$ and $\mathrm{p}(\mathrm{z})$ profiles are derived from a local climatology of radiosonde measurements or a standard atmosphere, scaled to the conditions of $\mathrm{T}(\mathrm{z})$ and $\mathrm{p}(\mathrm{z})$ of the surface station.

However, the atmospheric reanalysis can also be used to obtain $\mathrm{T}(\mathrm{z})$ and $\mathrm{p}(\mathrm{z})$ profiles at any station, but we found no reports of its use for this purpose. Both in elastic and Raman lidars, the temperature and pressure profiles are used to determine the molecular backscatter coefficient $[7,8]$. Three of the Latin America Lidar Network LALINET stations have an elastic lidar and five stations have a Raman lidar. Currently, Camaguey have not lidar station. However, not all LALINET stations currently has operative radiosonde measurements nearby. Therefore, the goal of this research is to determine the ERA-Interim reanalysis $\mathrm{T}(\mathrm{z})$ and $\mathrm{p}(\mathrm{z})$ profiles could replace the use of the standard atmosphere $\mathrm{T}(\mathrm{z})$ and $\mathrm{p}(\mathrm{z})$ profiles for the determination of the molecular backscatter coefficients profiles for the LALINET lidar stations.

The comparison of the mean $\mathrm{T}(\mathrm{z})$ profiles for LALINET stations derived from radiosonde measurements, the standard atmosphere and ERA-Interim reanalysis is conducted in a straightforward and easily reproducible manner. Section 2, briefly describes the radiosonde measurements, ERA-Interim and standard atmosphere datasets and the method of selection of the period for the comparison. The determination of the geometric altitude for the ERA-Interim dataset is explained. Also are described the statistics used to compare the $\mathrm{T}(\mathrm{z})$ profiles and molecular backscatter coefficient profiles. In Section 3, the differences of the $\mathrm{T}(\mathrm{z})$ profiles (root mean square error) and the differences of the molecular backscatter coefficient profiles (relative difference) are presented. In this section, also are present the considerations and discussion of the results. Finally, section 4 presents the conclusions of this work.

\section{Data and Method}

\section{2.a. LALINET}

The Latin America Lidar Network (LALINET) http://lalinet.org/ is a Latin American coordinated lidar network. It began as a series of bi-annual workshops in 2001, fostering a Latin American lidar community engaged on lidar measurements of aerosols and other atmospheric species such as ozone and water vapor. LALINET was formalized in 2013, becoming the youngest affiliate of the GAW Aerosol Lidar Observation Network (GALION) $[9,10,11]$. LALINET consists of groups from different countries of Latin America and is a contributing network to the Global Atmosphere Watch (GAW) via GALION [12]. Since January 2013, each lidar team has been performing lidar measurements, following protocols based on those initially defined for the pilot campaign [7]. The comparison of the inversion algorithms for lidar signal used by different lidar teams conducted to the standardization of the aerosols backscatter inversion algorithm for LALINET [11].

\section{2.b. Radiosonde measurements datasets}

Radiosonde measurements were obtained from the Integrated Global Radiosonde Archive (IGRA), the largest available collection of radiosonde observations. This collection consists of the radiosonde and pilot balloon observation records at more than 1500 globally distributed stations. At these stations the period of records is different, many of which extend from the 1960s to present. Observations include p(z), T(z), geopotential height, dew point depression, wind direction, and wind speed at the surface and the standard mandatory levels. Significant levels are also included, like the tropopause [13]. Eleven different sources of data were used in the compilation of the IGRA datasets. Rigorous quality control procedures were applied by the IGRA team to each station, eliminating duplicated levels within soundings, and guaranteeing the selection of only one sounding for each date and time at every station. Quality control algorithms detected formatting problems, physically improbable values, internal inconsistencies between variables, runs of values across soundings and levels, climatological outliers, and temporal and vertical inconsistencies in $\mathrm{T}(\mathrm{z})$ [14]. IGRA datasets are updated on daily basis. They are available online from NCDC in 
ftp://ftp.ncdc.noaa.gov/pub/data/igra. IGRA datasets consists of one file per station with the soundings ordered consecutively.

Seven of the LALINET stations are located in the same place or nearby to a sounding station archived in IGRA. The distance between the individuals' seven LALINET stations and its corresponding sounding station was calculated. Table 1 shows the latitude, longitude and altitude of the LALINET stations, together with the distance to the nearby sounding station, in case it exists, and the available period of observations. The geographical location of the LALINET stations is depicted on figure 1. Stations in yellow are the ones with nearby sounding station and the ones in red do not have a nearby sounding station.

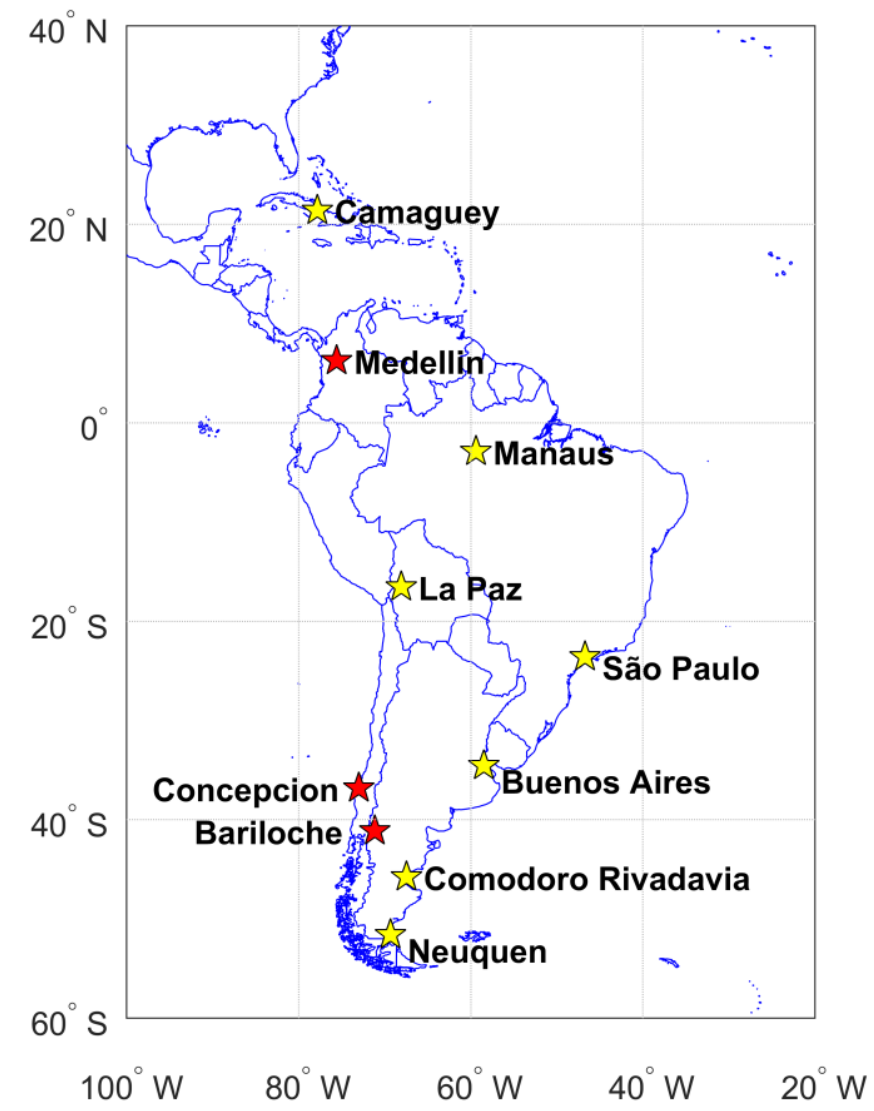

Fig. 1. LALINET stations distribution.

For the present study, we selected the following eight mandatory levels because they are representative of the troposphere, the current region of interest for LALINET aerosols measurements $(1000,850,700,500$, $400,300,200,100 \mathrm{hPa}) . \mathrm{T}(\mathrm{z})$, geometric height and the corresponding $\mathrm{p}(\mathrm{z})$ from all the mandatory levels were selected for each one of the seven available sounding stations in Table 1. After inspecting the completeness in time of the soundings for the seven sounding stations, the period 1979 - 2012 showed the higher amount of available data. During this period, soundings conducted at 00, 06 and 18 UTC showed more than $50 \%$ missing soundings for the seven sounding stations. Only the soundings conducted on 12 UTC had more than $50 \%$ of completeness, been the selected for the present study.

The monthly mean $\mathrm{T}(\mathrm{z})$ profiles and geometric height were calculated for the nine mandatory levels, producing the monthly mean geometric height profiles of $\mathrm{T}(\mathrm{z})$ and $\mathrm{p}(\mathrm{z})$. Those $\mathrm{T}(\mathrm{z})$ and $\mathrm{p}(\mathrm{z})$ geometric height profiles for each station were used to calculate the monthly mean profiles of the molecular backscatter coefficients for the seven available stations.

\section{2.c. ERA-Interim datasets}

The ERA-Interim reanalysis [15] is a homogeneous atmospheric reanalysis starting from 1979 and extending up to the present. It is based on the Integrated Forecast System (IFS) cycle 31r2 run of the European Centre for Medium Range Weather Forecasts. ERA-Interim reanalysis have 60 vertical levels and TL255 horizontal spectral resolution. This corresponds to a horizontal grid spacing of about $80 \mathrm{~km}$. 
Observations are assimilated into ERA-Interim using a four-dimensional variational data assimilation scheme with 12-h cycling [16] and outputs every $6 \mathrm{~h}$. In ERA-Interim, upper air data are saved on each of the 60 "full" model levels and on 37 pressure levels (see Table 2 in [17]). From these 37 pressure levels only were selected the surface and the eight mandatory levels cited above (i.e. 1000, 850, 700, 500, 400, 300, 200, $100 \mathrm{hPa}$ ). The ERA-Interim data used in this study was obtained from the ECMWF data server on a fixed grid of $0.5^{\circ}$ resolution.

Table 1. LALINET stations

\begin{tabular}{|c|c|c|c|c|c|}
\hline City, Country & Lat & Long & Elevation (m.a.s.l) & Available period & Distance to sounding station $(\mathrm{km})$ \\
\hline Medellín, Colombia & $6.26^{\circ} \mathrm{N}$ & 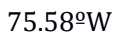 & 1538 & - & There is not station \\
\hline Manaus, Brazil & $2.89^{\circ} \mathrm{S}$ & 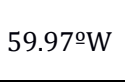 & 100 & $\begin{array}{c}\text { June } 1968 \text { to } \\
\text { present }\end{array}$ & 28.93 \\
\hline La Paz, Bolivia & $16.54^{\circ} \mathrm{S}$ & $68.07^{\circ}-\mathrm{W}$ & 3420 & $\begin{array}{c}\text { May } 1971 \text { to } \\
\text { April } 2012 \\
\end{array}$ & 14.25 \\
\hline São Paulo, Brazil & $23.56^{\circ} \mathrm{S}$ & $46.74^{\circ} \mathrm{o}$ & 740 & $\begin{array}{l}\text { May } 1970 \text { to } \\
\text { October } 2000\end{array}$ & 11.34 \\
\hline $\begin{array}{c}\text { Buenos Aires, } \\
\text { Argentina }\end{array}$ & $34.56^{\circ} \mathrm{S}$ & $58.51^{\circ} \mathrm{W}$ & 20 & $\begin{array}{c}\text { October } 1958 \text { to } \\
\text { present }\end{array}$ & 28.97 \\
\hline Concepción, Chile & $36.84^{\circ} \mathrm{S}$ & $73.02^{\circ} \mathrm{W}$ & 170 & - & There is not station \\
\hline Neuquén, Argentina & $38.95^{\circ} \mathrm{S}$ & $68.14^{\circ} \mathrm{W}$ & 271 & $\begin{array}{c}\text { January } 1958 \text { to } \\
\text { August } 2014 \\
\end{array}$ & 0.86 \\
\hline Bariloche, Argentina & $41.15^{\circ} \mathrm{S}$ & $71.16 \div \mathrm{W}$ & 840 & - & There is not station \\
\hline $\begin{array}{c}\text { Comodoro Rivadavia, } \\
\text { Argentina }\end{array}$ & $45.79^{\circ} \mathrm{S}$ & $67.46^{\circ} \mathrm{W}$ & 49 & $\begin{array}{c}\text { January } 1958 \text { to } \\
\text { present }\end{array}$ & 1.36 \\
\hline Camagüey, Cuba $\left({ }^{*}\right)$ & $21.42^{\circ} \mathrm{N}$ & $77.85^{\circ} \mathrm{W}$ & 122 & $\begin{array}{c}\text { October } 1966 \text { to } \\
\text { April } 1995\end{array}$ & 0.0 \\
\hline
\end{tabular}

${ }^{*}$ ) No lidar station operative currently at Camagüey, Cuba.

The first step consisted in selecting the series of six-hourly ERA-Interim reanalysis temperatures ( $\mathrm{T}_{\text {ERA }}$ ) and geopotentials $\left(\mathrm{G}_{\mathrm{ERA}}\right)$ at $12 \mathrm{UTC}$ for the period 1979 to 2012 . Following, the selection was narrowed to the series of $\mathrm{T}_{\mathrm{ERA}}$ and $\mathrm{G}_{\mathrm{ERA}}$ for the four grid points enclosing each one of the seven sounding stations. Finally, only the surface and the eight mandatory levels of $\mathrm{T}_{\mathrm{ERA}}$ and $\mathrm{G}_{\mathrm{ERA}}$ were considered. These procedure generated seven series of $T_{E R A}$ and $G_{E R A}$ for the period $1979-2012$ at 12 UTC, for the surface and eight mandatory $\mathrm{p}(\mathrm{z})$ levels, at the four grid points enclosing the seven sounding stations.

The nearest grid point value of the four $\mathrm{T}_{\mathrm{ERA}}$ series with respect to the location of the sounding station was selected and the geopotential was transformed to geopotential height $\left(\mathrm{H}_{\mathrm{ERA}}\right)$ by:

$$
\mathrm{H}_{\mathrm{ERA}}=\mathrm{G}_{\mathrm{ERA}} / g_{0} \text {; }
$$

where $g_{0}=9.80665 \mathrm{~m} / \mathrm{s}^{2}$ is the standard gravity. Later, geopotential height was converted to geometric height for all pressure levels. The acceleration of gravity for sea level at latitude $\phi$ was calculated by [18]:

$$
g_{\phi}=9.780327\left(1+5.2885 \cdot 10^{-3} \sin ^{2} \phi-5.9 \cdot 10^{-6} \sin ^{2} 2 \phi\right) ;
$$

and the geometric height was calculated by:

$$
\mathrm{Z}_{\mathrm{ERA}}=\frac{r_{0} \cdot \mathrm{H}_{\mathrm{ERA}}}{\Gamma \cdot r_{0}-\mathrm{H}_{\mathrm{ERA}}}
$$

where [18]

$$
\Gamma=g_{\phi} / g_{0}
$$

and $r_{0}$ is the effective earth's radius for purposes of calculating geopotential at any latitude. The values of $r_{0}$ was calculated by [18]:

$$
r_{0}=\frac{2 g_{\phi}}{3.085462 \cdot 10^{-6}+2.27 \cdot 10^{-9} \cos 2 \phi-2 \cdot 10^{-12} \cos 4 \phi} ;
$$

We use the 12 UTC datasets from ERA-Interim to have a coincident time scale to the radiosonde measurements dataset. Then, as in the case of the series of radiosonde measurements, monthly mean 
profiles of $\mathrm{T}(\mathrm{z})$ and $\mathrm{p}(\mathrm{z})$ were calculated. Finally, the monthly means profiles of the molecular backscatter coefficients were calculated for the selected stations.

\section{2.d. U.S. Standard Atmosphere 1976 (USSA-1976)}

A standard atmosphere depicts idealized middle-latitude year-round mean conditions for the range of solar activity that occurs between sunspot minimum and sunspot maximum [19]. The U.S. Standard Atmosphere, 1976 (USSA-1976) is based on an existing international standard, which was first published in 1958 by the U.S. Committee on Extension to the Standard Atmosphere, and was updated in 1962 and 1966. The USSA1976 is a representation of the Earth's atmosphere from the surface to $1000 \mathrm{~km}$. It also establish numerical values for various constants appropriate to the Earth's atmosphere, such as the standard acceleration due to gravity, the sea level mean molar mass, the Avogadro constant and others adopted for the calculation of the USSA-1976 parameters. The quantity $g_{0}$ represents the sea-level value of the gravity acceleration adopted for this standard. This value is the one originally adopted by the International Committee on Weights and Measures in 1901 for $45^{\circ}$ latitude, even though it applies more precisely to the latitude $45^{\circ} 32^{\prime}$ $33 "$ for this standard [20].

We used T(z), p(z), density for geopotential and geometric altitudes profiles in metric units from USSA1976. The USSA-1976 reported variables only represent the yearly mean values of the atmospheric variables for the pressure levels, and do not represent the monthly mean profiles for each variable.

\section{2.e. Temperature profiles comparison}

Because the vertical variability of $\mathrm{T}(\mathrm{z})$ is higher than $\mathrm{p}(\mathrm{z}), \mathrm{T}(\mathrm{z})$ is the atmospheric variable causing most of the variability in the molecular backscatter coefficient according to equation 2 . That is the reason for conducting the comparison between radiosonde daily $\mathrm{T}(\mathrm{z})$ profiles with the spatio-temporal coincident ERA-Interim daily $\mathrm{T}(\mathrm{z})$ profiles for the whole period of study. The radiosonde daily $\mathrm{T}(\mathrm{z})$ profiles were also compared against the USSA-1976 (z) profile. The statistical evaluation of the differences was conducted using the Root Mean Square Error (RMSE):

$$
R M S E=\sqrt{\sum_{i=1}^{n} \frac{\left(\mathrm{M}_{i}-O_{i}\right)^{2}}{n}} ;
$$

where $n$ is the number of elements in both series. The $i$ denotes the element number, $M_{i}$ is the time and mandatory level coincident $\mathrm{T}(\mathrm{z})$ from ERA-Interim or the mandatory level coincident mean $\mathrm{T}(\mathrm{z})$ from the USSA-1976 values; $O_{i}$ is the time and mandatory level coincident T(z) from radiosonde measurements values (expected value). BIAS was also used for comparing the monthly mean $\mathrm{T}(\mathrm{z})$ profiles from the radiosonde measurements with the monthly mean $\mathrm{T}(\mathrm{z})$ profiles from ERA-Interim and with the USSA-1976 $\mathrm{T}(\mathrm{z})$ profile. BIAS is defined as:

$$
B I A S=\frac{1}{n} \sum_{i=1}^{n}\left(M_{i}-O_{i}\right) ;
$$

RMSE and BIAS were determined for each one of the mandatory levels and for all the mandatory levels together.

\section{2.f. Comparison of the molecular backscatter coefficient at $532 \mathrm{~nm}$ for radiosonde measurements dataset vs USSA-1976 and for radiosonde measurements dataset vs ERA-Interim dataset}

The monthly mean profiles of molecular backscatter coefficient at $532 \mathrm{~nm}$ is calculated with equation (2). Monthly mean profiles of $\mathrm{T}(\mathrm{z})$ and $\mathrm{p}(\mathrm{z})$ derived from the stations soundings and from the ERA-Interim are used. A mean profile of the molecular backscatter coefficient is calculated in the case of the USSA-1976. The statistical evaluation of the comparison between radiosonde measurements monthly mean profiles of molecular backscatter coefficient with the USSA-1976 profile of molecular backscatter coefficient and the ERA-Interim monthly mean profiles of molecular backscatter is conducted using the Relative Error (RE) in percent. This statistic is defined as [21]:

$$
R E=\frac{M_{i}-O_{i}}{O_{i}} \cdot 100 \% ;
$$

The mean, maximum and minimum values from the daily molecular backscatter coefficient are determined. Monthly mean profiles of the molecular backscatter coefficient at $532 \mathrm{~nm}$ are calculated from ERA-Interim and radiosonde measurements. In addition, the annual mean profile of the molecular backscatter coefficient at $532 \mathrm{~nm}$ from ERA-Interim and radiosonde measurements. The annual mean profile of the molecular backscatter coefficient at $532 \mathrm{~nm}$ from the USSA-1976 was also calculated. 


\section{Results and discussion}

\section{3.a. $T(z)$ profiles comparison.}

Figure 2 shows the profiles of T(z) BIAS for the comparison between the T(z) profile from USSA-1976 and $\mathrm{T}(\mathrm{z})$ yearly mean profile from radiosonde measurements and for the comparison between the T(z) yearly mean profile from ERA-Interim reanalysis and radiosonde measurements T(z) yearly mean profile. The T(z) BIAS between USSA-1976 and radiosonde measurements (green curve) show a negative BIAS from the surface to $12 \mathrm{~km}$ for almost all stations, except in Neuquen where the negative BIAS is observed from surface to $9 \mathrm{~km}$ and positive values of BIAS above those altitudes. In the case of Comodoro Rivadavia positive BIAS are observed in all profile at intervals of around $5 \mathrm{~km}$ from the surface. The maximum BIAS between USSA1976 and radiosonde measurements is seen from 6 to $8 \mathrm{~km}$ with values greater than $12 \mathrm{~K}$. At Neuquen and Comodoro Rivadavia stations the lowest $\mathrm{T}(\mathrm{z})$ differences between the radiosonde measurements and the USSA-1976 are present, with BIAS smaller than $5 \mathrm{~K}$ at all altitudes in both profiles. These two stations are located in middle latitudes the region of definition of the USSA-1976. In the figures is clearly observed that the T(z) BIAS between ERA-Interim reanalysis and radiosonde measurements are smaller than $2 \mathrm{~K}$, and only Camagüey station shows T(z) differences greater than $3 \mathrm{~K}$ in the altitude region above $9 \mathrm{~km}$.
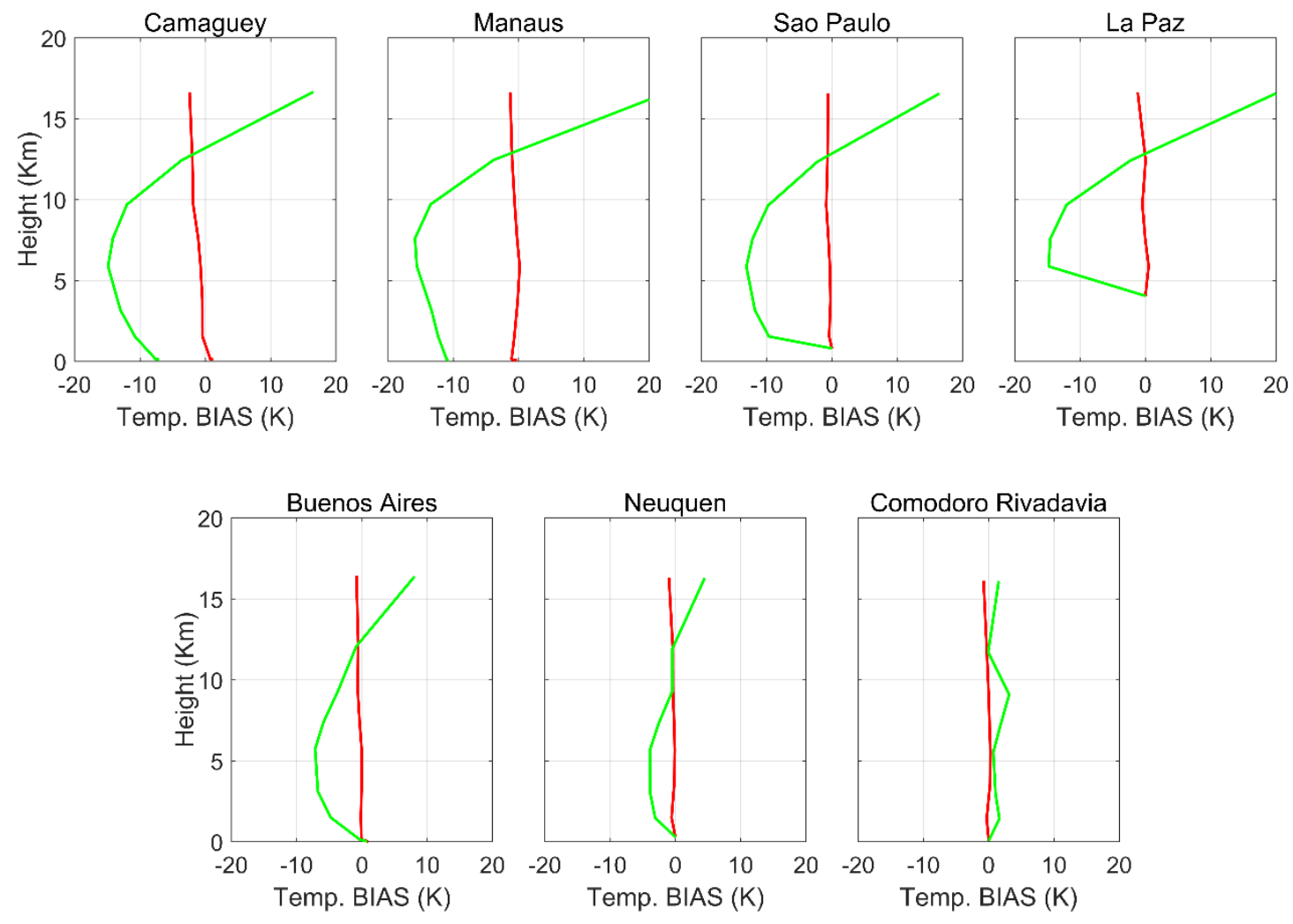

- Radiosonde measurements vs. ERA-Interim

Radiosonde measurements vs. USSA-1976

Fig. 2. T(z) BIAS profiles for the comparison between radiosonde measurements and the ERA-Interim in red lines and between radiosonde measurements and the USSA-1976, in green lines

Former results demonstrate that the BIAS of the ERA-Interim T(z) daily profiles with respect to the radiosonde measurements T(z) daily profiles are much lower than the BIAS of the USSA-1976 for the same radiosonde measurements $\mathrm{T}(\mathrm{z})$ daily profiles. That is valid for all the stations in this study, covering the latitude band from the tropical northern hemisphere to high latitudes in the southern hemisphere. The BIAS in the case of the USSA-1976 in several cases is one order of magnitude larger than the BIAS for the ERAInterim.

Figure 3 shows the annual course of the RMSE between radiosonde measurements T(z) daily profiles and ERA-Interim T(z) daily profiles on top panel. Bottom panel shows the monthly RMSE between radiosonde measurements $\mathrm{T}(\mathrm{z})$ daily profiles and USSA-1976 $\mathrm{T}(\mathrm{z})$ profile. The RMSE between radiosonde 
measurements and ERA-Interim are smaller than the RMSE between radiosonde measurements and USSA1976. In many stations, the RMSE between radiosonde measurements and ERA-Interim have RMSE values smaller than $2 \mathrm{~K}$, and most of the altitude levels show RMSE values smaller than $1 \mathrm{~K}$. Only Camagüey, La Paz and Neuquen stations present RMSE values greater than 2 K. Camagüey station have RMSE greater than 2 $\mathrm{K}$ only above $8 \mathrm{~km}$, although not in every month, because July and October present RMSE values smaller than $2 \mathrm{~K}$ at every altitude. At this station the first five months present RMSE values greater than $3 \mathrm{~K}$ above $10 \mathrm{~km}$. In La Paz station, the RMSE values greater than $3 \mathrm{~K}$ are shown between May and August from the surface to $6 \mathrm{~km}$ and the RMSE are greater than $4 \mathrm{~K}$ at the surface. However, in Neuquen station the RMSE values greater than $3 \mathrm{~K}$ are shown in the months from January to March and between October and December from surface to $1 \mathrm{~km}$.

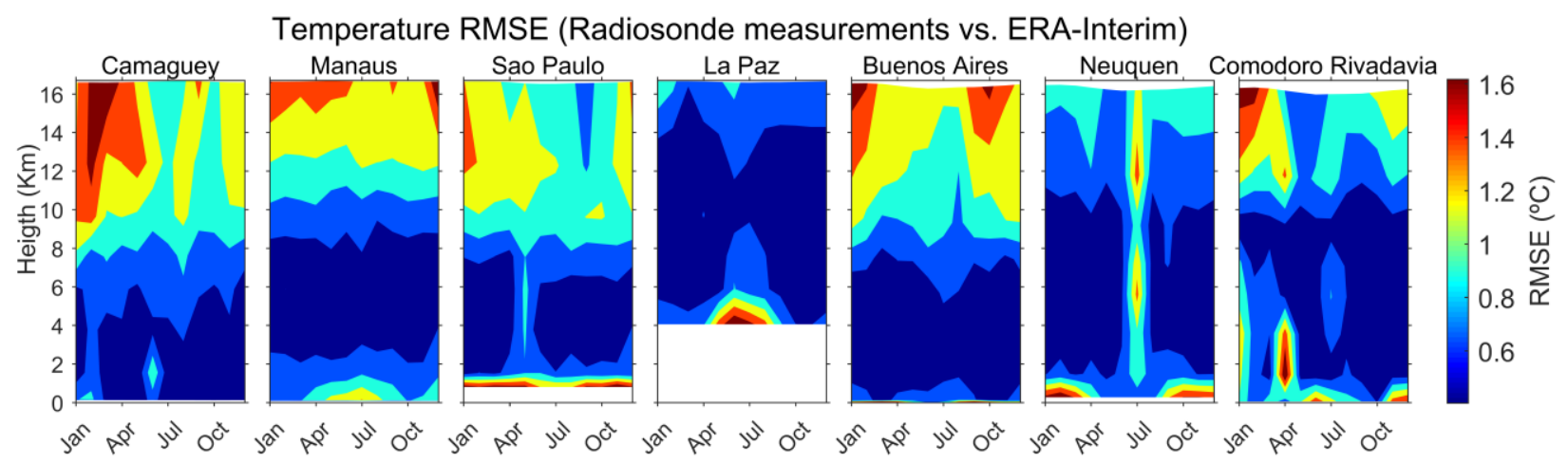

Temperature RMSE (Radiosonde measurements vs. USSA-1976)

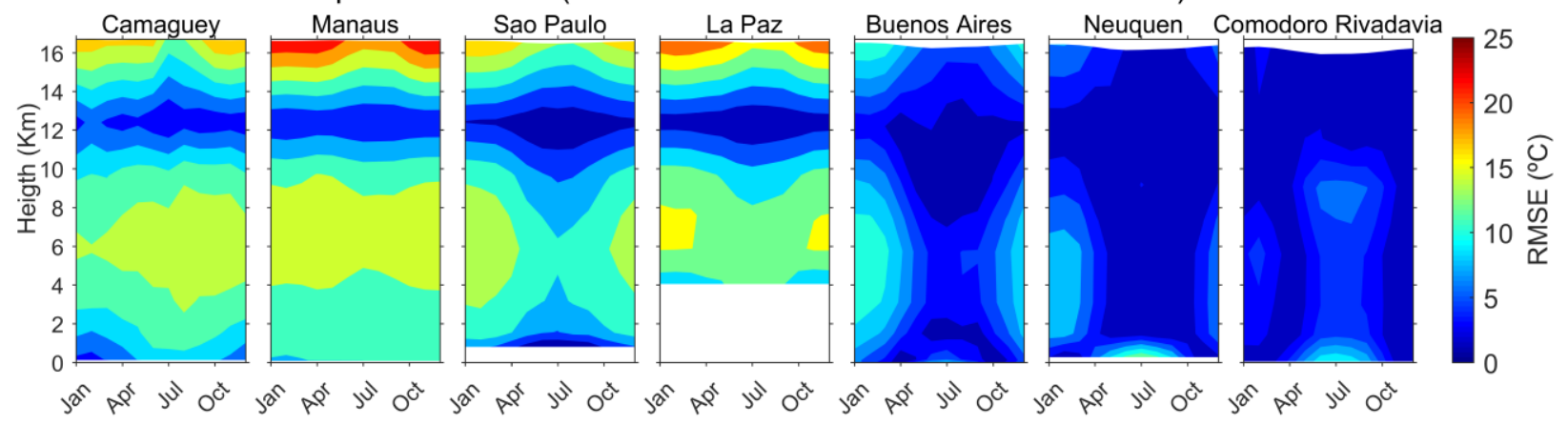

Fig. 3. Annual course of the T(z) Root Mean Square Error vertical distribution for the comparison between radiosonde measurements and the ERA-Interim T(z) s on the top and between radiosonde measurements and the USSA-1976 T(z) s in the bottom. Note: Upper and lower panels have different color scale for legend.

The RMSE between radiosonde measurements and USSA-1976 are greater than those observed previously (radiosonde measurements vs ERA-Interim). Buenos Aires, Neuquen and Comodoro Rivadavia are the only stations that present differences smaller than $10 \mathrm{~K}$ at all altitudes in the case of the USSA-1976. The other stations present differences greater than $15 \mathrm{~K}$ in the altitude region from 4 to $6 \mathrm{~km}$ and only Manaus station have differences greater than $20 \mathrm{~K}$, but above $15 \mathrm{~km}$. The annual course of the RMSE ratifies the results for the BIAS between yearly mean T(z) profiles; the ERA-Interim T(z) profiles match better the radiosonde measurements $\mathrm{T}(\mathrm{z})$ profiles than the USSA-1976.

\section{3.b. Molecular backscatter coefficient comparison.}

Table 2 reports the statistics of the RE in percent of the daily molecular backscatter at $532 \mathrm{~nm}$ for all mandatory levels between radiosonde measurements and ERA-Interim and between radiosonde measurements and the USSA-1976. Mean RE values for the comparison between radiosonde measurements and ERA-Interim are in the order of $0.1 \%$. Maximum RE values are in the range of $4.52 \%$ to $1.5 \%$ and the minimum RE values from $-4.84 \%$ to $-1.05 \%$ percent. Only Camagüey and Neuquen have minimum values greater than $2 \%$. The RE between radiosonde measurements and USSA-1976 shows mean values below 1 $\%$ in La Paz, Buenos Aires and Neuquen. Comodoro Rivadavia station have a mean of $-0.68 \%$ and the others stations have means between $2.17 \%$ and $3.01 \%$. However, the standard deviation in all stations are greater than $1 \%$, with more than $3 \%$ in Camagüey and more than $4 \%$ in Manaus and Sao Paulo. The maximum RE 
values are greater than $6 \%$ in Camagüey, Manaus, Sao Paulo and La Paz and the minimum values are smaller than $-10 \%$ in the same stations. At the other stations, the maximum values are greater than $3 \%$ and the minimum values are smaller than $-4 \%$. The mean value RE for the ERA-Interim is $0.16 \% \pm 0.47 \%$ and for the USSA-1976 is $1.52 \% \pm 3.49 \%$. It means the maximum error using the ERA-Interim will be $0.63 \%$ while for the USSA-1976 it will be $5.01 \%$. Taking into account the RE has been defined in this study with respect to radiosonde measurements, we may consider the absolute error introduced by ERA-Interim to determine the molecular backscatter coefficient as the sum of RE plus the absolute error when radiosonde measurements are used. Considering that the absolute error using the radiosonde to calculate the molecular backscatter coefficient is reported as $1 \%$ [21] the absolute error for the ERA-Interim will be $1.63 \%$ and for the USSA-1976, it will be $6.01 \%$. The value of $6.01 \%$ obtained for the USSA-1976 doubles the former estimate for modelled or interpolated molecular backscatter coefficient error [21].

Table 2. Statistics of the RE in percent of the daily molecular backscatter coefficient at $532 \mathrm{~nm}$ for all mandatory levels between radiosonde measurements and ERA-Interim and between radiosonde measurements and the USSA-1976.

\begin{tabular}{|c|c|c|c|c|c|c|}
\cline { 2 - 7 } \multicolumn{1}{c|}{} & \multicolumn{2}{c|}{ RE(\%) ERA-Interim } & \multicolumn{3}{c|}{ RE(\%) USSA-1976 } \\
\hline \hline Stations & Mean & Max & Min & Mean & Max & Min \\
\hline Camagüey & $0.33 \pm 0.78$ & 4.52 & -3.18 & $2.85 \pm 3.96$ & 7.42 & -11.54 \\
\hline Manaus & $0.26 \pm 0.37$ & 5.02 & -1.07 & $3.01 \pm 4.96$ & 7.41 & -12.83 \\
\hline Sao Paulo & $0.14 \pm 0.35$ & 1.50 & -1.12 & $2.17 \pm 4.09$ & 6.86 & -10.40 \\
\hline La Paz & $0.16 \pm 0.56$ & 3.83 & -1.60 & $0.87 \pm 5.81$ & 7.28 & -11.61 \\
\hline Buenos Aires & $0.11 \pm 0.39$ & 1.83 & -1.05 & $0.86 \pm 2.36$ & 5.27 & -7.21 \\
\hline Neuquen & $0.08 \pm 0.48$ & 4.26 & -4.84 & $0.22 \pm 1.93$ & 4.62 & -6.11 \\
\hline Comodoro Rivadavia & $0.05 \pm 0.36$ & 3.55 & -1.78 & $-0.68 \pm 1.38$ & 3.12 & -4.98 \\
\hline \hline
\end{tabular}

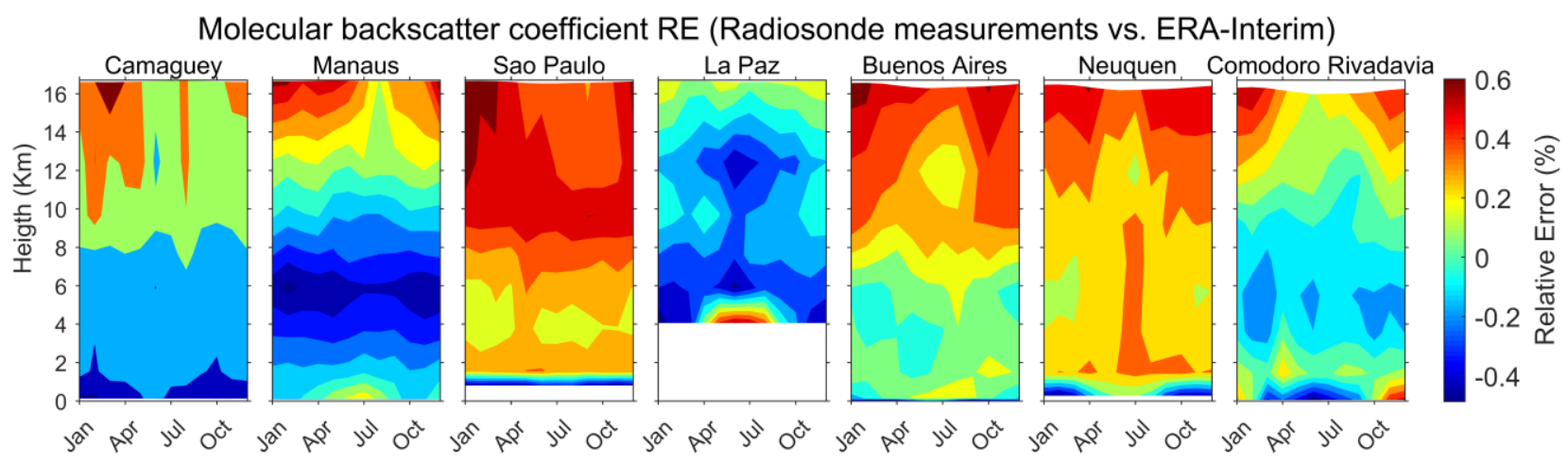

Molecular backscatter coefficient RE (Radiosonde measurements vs. USSA-1976

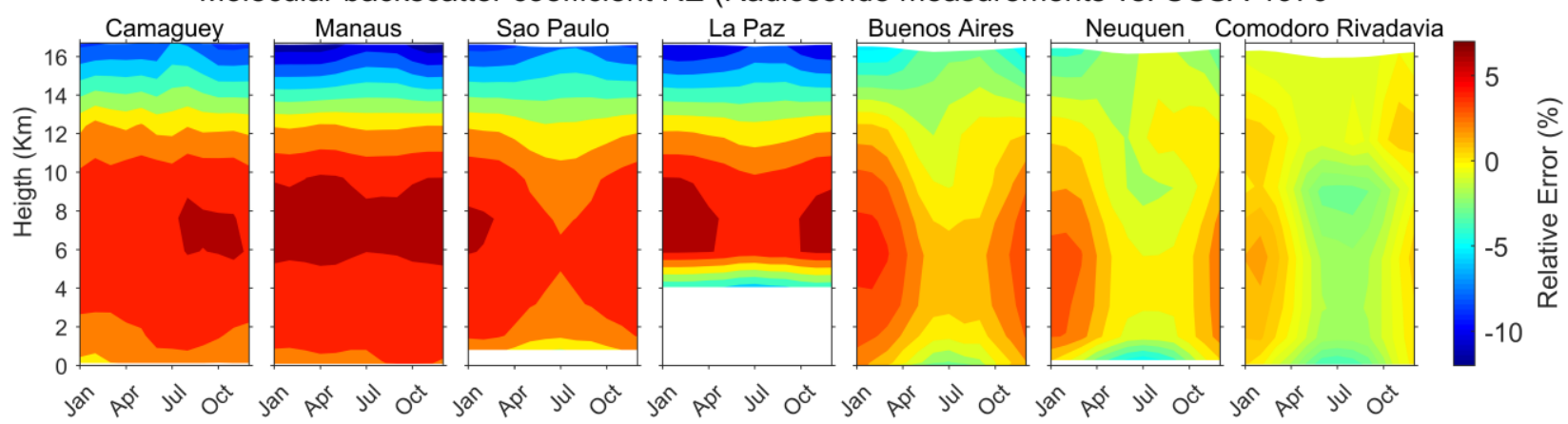

Fig. 4. Relative Error of Molecular Backscatter Coefficient for $532 \mathrm{~nm}$, between radiosonde measurements and ERA-Interim and between radiosonde measurements and USSA-1976. Note: Upper and lower panels have different color scale for legend.

Figure 4 shows the annual course profiles of the molecular backscatter coefficient RE between radiosonde measurements and ERA-Interim and between radiosonde measurements and USSA-1976. RE profiles between radiosonde measurements and ERA-Interim present values smaller than $0 \%$ in most of the mandatory levels. RE values, greater than $0.5 \%$ are located above $8 \mathrm{~km}$, except in Manaus and La Paz where 
RE values greater than $0.5 \%$ and $1.5 \%$ respectively appear at the surface, from April to August. In Camagüey station, the RE is greater than $1.5 \%$ in March and RE values greater than $1.5 \%$ from January to May, in August, in November and December, in all case above $10 \mathrm{~km}$. However, the monthly mean profiles RE between radiosonde measurements and USSA-1976 shows positive RE values from surface to $12 \mathrm{~km}$ in all stations, although in Buenos Aires, Neuquen and Comodoro Rivadavia are observed some month with RE values smaller than $-5 \%$ at surface level, and in La Paz station in all months at the surface level too. In Camagüey, Manaus, Sao Paulo and La Paz negative RE values are observed above $14 \mathrm{~km}$ with RE values smaller than -5\%. RE values between radiosonde measurements and USSA-1976 at Comodoro Rivadavia show the best results among all the radiosonde measurements compared to the USSA-1976 because this station is located near to middle latitudes, the region of definition of the USSA-1976. Even in this station, the RE values between radiosonde measurements and the USSA-1976 than those observed between radiosonde measurements and ERA-Interim.

\section{3.c. Standardizing the determination of the molecular backscatter coefficient for LALINET lidars}

According to the available information only four lidar stations has sounding stations operatives currently, two in Brazil (São Paulo and Manaus) and the other two in Argentina (Buenos Aires and Comodoro Rivadavia). At the other five lidar stations (including the three elastic lidars at Medellin, La Paz and Concepción) no radiosonde measurements are available. The solution in those three cases for deriving the molecular backscattering coefficient has been using the USSA-1976.

The results shown and discussed above demonstrate that the use of the ERA-Interim reanalysis reduces notably the error to determine the molecular backscatter coefficient produced when the USSA-1976 is used for that purpose. This fact supports the replacement of the USSA-1976 by ERA-Interim reanalysis to determine the molecular backscatter coefficient at the LALINET elastic lidar stations with no available radiosonde measurements. For such a purpose we have calculated the monthly mean profiles of T(z) and p(z) for each LALINET lidar station for the period 1979 to 2012 at 12 UTC. T(z) at the surface and eight mandatory $\mathrm{p}(\mathrm{z})$ levels described above, were selected at the nearest grid point to the station from the four grid points enclosing it. Then monthly means molecular backscatter coefficient profiles were calculated for each one of the seven stations. These dataset has been provided to LALINET Teams by personal communication and it is located at GOAC's web http://www.goac.cu/lalinet/.

There is the additional option to use the ERA-Interim $\mathrm{T}(\mathrm{z})$ profiles at the $\mathrm{p}(\mathrm{z})$ mandatory levels for the same day and the nearest time the lidar measurement has been conducted. Then the molecular backscatter coefficient profile could be calculated. Implementing the procedure for it is simple and straightforward.

Additionally, we suggest deriving the molecular backscatter coefficient from daily ERA-Interim reanalysis at all the LALINET lidar stations, for the processing of the contributed measurements to LALINET to guarantee an homogeneous level of error in the molecular backscatter coefficient.

\section{Conclusions}

The comparison of $\mathrm{T}(\mathrm{z}), \mathrm{p}(\mathrm{z})$ and the molecular backscatter profiles derived from the radiosonde measurements, ERA-Interim and USSA-1976 has been conducted. Two temporal scales have been considered, daily and monthly means. At both temporal scales, the BIAS and the RMSE show the ERAInterim T(z) profiles better representing the radiosonde measurements $T(z)$ profiles than the USSA-1976 $\mathrm{T}(\mathrm{z})$ profile. The mean value RE for the determination of the molecular backscatter coefficient in the case of the ERA-Interim is $0.16 \% \pm 0.47 \%$ and for the USSA-1976 it is $1.52 \% \pm 3.49 \%$, taking the radiosonde measurements as reference. The absolute error for ERA-Interim is $1.63 \%$ and for the USSA-1976, it will be $6.01 \%$.

These results shows that the ERA-Interim datasets represent both the daily $\mathrm{T}(\mathrm{z})$ and $\mathrm{p}(\mathrm{z})$ profiles and its corresponding climatology better than the USSA-1976, for the LALINET stations. The same conclusion is valid for the determination of the molecular backscatter profiles. A standardization of the molecular backscatter coefficient determination for LALINET stations is proposed supported by those results. It includes the use of daily and climatological $\mathrm{T}(\mathrm{z})$ and $\mathrm{p}(\mathrm{z})$ [profiles from ERA-Interim]. The molecular backscatter coefficient deriving from daily ERA-Interim reanalysis, will guarantee an homogeneous error in the molecular backscatter coefficient when the network lidar measurements are processed together. 


\section{Acknowledgements}

Authors express its gratitude to the European Centre for Medium-Range Weather Forecasts (ECMWF) and Integrated Global Radiosonde Archive (radiosonde measurements) for making the data publicly available. Also especially thank to the Organizer Committee of the IX Workshop on Lidar Measurements in Latin America. Portions of this work were presented at the IX Workshop on Lidar Measurements in Latin America in Poster entitle "Standardizing the determination of the molecular backscatter coefficient profiles for LALINET elastic lidar stations using ERA-Interim Reanalysis", 2016. This study was supported by the grant P211LH007-020 from the Cuban National Research Program "Meteorology and sustainable development of the country". 
In the case of elastic lidars the problem consists in determining two unknowns, the molecular and aerosols backscatter coefficients with only one equation. The solution is to determine the molecular backscatter using an additional equation [5]:

$$
\beta_{m o l}(R, \lambda ; p, T)=\frac{9 \pi^{2}\left(m_{\text {air }}{ }^{2}-1\right)^{2}}{\lambda^{4} N_{s}^{2}\left(m_{\text {air }}{ }^{2}+2\right)^{2}} \cdot \frac{6+3 \gamma}{6-7 \gamma} \cdot N_{S} \cdot \frac{T_{0}}{p_{0}} \cdot \frac{p(z)}{T(z)}
$$

where $m_{\text {air }}$ is the refractive index of the air, $\gamma$ is the depolarization factor $(\gamma$ is $0.0301,0.02$, and 0.0273 for 355,532 , and $1064 \mathrm{~nm}$, respectively) [6], $N_{S}$ is the molecular number density $\left(N_{S}=2.547 \cdot 10^{19} \mathrm{~cm}^{-3}\right)$ for standard atmospheric conditions at ground level $\left(p_{0}=1013.25 \mathrm{hPa}, \mathrm{T}_{0}=15^{\circ} \mathrm{C}\right.$ and $\left.0.03 \% \mathrm{CO}_{2}\right)$. Profiles of temperature $\mathrm{T}(\mathrm{z})$ and pressure $\mathrm{p}(\mathrm{z})$ are obtained from radiosonde measurements. In absence of radiosonde measurements $\mathrm{T}(\mathrm{z})$ and $\mathrm{p}(\mathrm{z})$ profiles are derived from a local climatology of radiosonde measurements or a standard atmosphere, scaled to the conditions of $\mathrm{T}(\mathrm{z})$ and $\mathrm{p}(\mathrm{z})$ of the surface station.

However, the atmospheric reanalysis can also be used to obtain $\mathrm{T}(\mathrm{z})$ and $\mathrm{p}(\mathrm{z})$ profiles at any station, but we found no reports of its use for this purpose. Both in elastic and Raman lidars, the temperature and pressure profiles are used to determine the molecular backscatter coefficient $[7,8]$. Three of the Latin America Lidar Network LALINET stations have an elastic lidar and five stations have a Raman lidar. Currently, Camaguey have not lidar station. However, not all LALINET stations currently has operative radiosonde measurements nearby. Therefore, the goal of this research is to determine the ERA-Interim reanalysis $\mathrm{T}(\mathrm{z})$ and $\mathrm{p}(\mathrm{z})$ profiles could replace the use of the standard atmosphere $T(z)$ and $p(z)$ profiles for the determination of the molecular backscatter coefficients profiles for the LALINET lidar stations.

The comparison of the mean $\mathrm{T}(\mathrm{z})$ profiles for LALINET stations derived from radiosonde measurements, the standard atmosphere and ERA-Interim reanalysis is conducted in a straightforward and easily reproducible manner. Section 2, briefly describes the radiosonde measurements, ERA-Interim and standard atmosphere datasets and the method of selection of the period for the comparison. The determination of the geometric altitude for the ERA-Interim dataset is explained. Also are described the statistics used to compare the T(z) profiles and molecular backscatter coefficient profiles. In Section 3, the differences of the $\mathrm{T}(\mathrm{z})$ profiles (root mean square error) and the differences of the molecular backscatter coefficient profiles (relative difference) are presented. In this section, also are present the considerations and discussion of the results. Finally, section 4 presents the conclusions of this work.

\section{Data and Method}

\section{2.a. LALINET}

The Latin America Lidar Network (LALINET) http://lalinet.org/ is a Latin American coordinated lidar network. It began as a series of bi-annual workshops in 2001, fostering a Latin American lidar community engaged on lidar measurements of aerosols and other atmospheric species such as ozone and water vapor. LALINET was formalized in 2013, becoming the youngest affiliate of the GAW Aerosol Lidar Observation Network (GALION) $[9,10,11]$. LALINET consists of groups from different countries of Latin America and is a contributing network to the Global Atmosphere Watch (GAW) via GALION [12]. Since January 2013, each lidar team has been performing lidar measurements, following protocols based on those initially defined for the pilot campaign [7]. The comparison of the inversion algorithms for lidar signal used by different lidar teams conducted to the standardization of the aerosols backscatter inversion algorithm for LALINET [11].

\section{2.b. Radiosonde measurements datasets}

Radiosonde measurements were obtained from the Integrated Global Radiosonde Archive (IGRA), the largest available collection of radiosonde observations. This collection consists of the radiosonde and pilot balloon observation records at more than 1500 globally distributed stations. At these stations the period of records is different, many of which extend from the 1960s to present. Observations include p(z), T(z), geopotential height, dew point depression, wind direction, and wind speed at the surface and the standard mandatory levels. Significant levels are also included, like the tropopause [13]. Eleven different sources of data were used in the compilation of the IGRA datasets. Rigorous quality control procedures were applied by the IGRA team to each station, eliminating duplicated levels within soundings, and guaranteeing the selection of only one sounding for each date and time at every station. Quality control algorithms detected formatting problems, physically improbable values, internal inconsistencies between variables, runs of values across soundings and levels, climatological outliers, and temporal and vertical inconsistencies in $\mathrm{T}(\mathrm{z})$ [14]. IGRA datasets are updated on daily basis. They are available online from NCDC in 